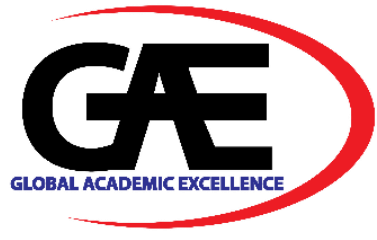

\title{
PRE-UNIVERSITY ONLINE EXAMINATION DURING PANDEMIC COVID-19: EXPERIENCES AND CHALLENGES
}

\author{
Ayu Afiqah Nasrullah ${ }^{1}$, Sitty Nur Syafa Bakri ${ }^{2}$, Mohd Azrul Abdul Rajak ${ }^{3}$, Fadzilah Awang-Kanak ${ }^{4}$ \\ 1 Preparatory Centre for Science and Technology, Universiti Malaysia Sabah, Malaysia \\ Email: ayu.afiqah@ums.edu.my \\ 2 Preparatory Centre for Science and Technology, Universiti Malaysia Sabah, Malaysia \\ Email: syafa@ums.edu.my \\ 3 Preparatory Centre for Science and Technology, Universiti Malaysia Sabah, Malaysia \\ Email: azrulrajak88@ums.edu.my \\ 4 Preparatory Centre for Science and Technology, Universiti Malaysia Sabah, Malaysia \\ Email: akfadzil@ums.edu.my \\ Corresponding Author
}

\section{Article Info:}

Article history:

Received date: 11.09 .2021

Revised date: 10.10 .2021

Accepted date: 15.11 .2021

Published date: 30.11 .2021

\section{To cite this document:}

Nasrullah, A. A., Bakri, S. N. S., Rajak, M. A. A., \& Awang-Kanak, F. (2021). Pre-University Online Examination During Pandemic COVID-19: Experiences and Challenges. Journal of Information System and Technology Management, 6 (23), 156-163.

DOI: $10.35631 /$ JISTM.623014

This work is licensed under $\underline{\mathrm{CC} B Y} 4.0$ (c) 1

\section{Abstract:}

Over the last decade, online examinations have been widely practiced in both the private and government sector. Working professionals preferred the online examination because it provides them with the flexibility of time and location. However, it is not a common practice in educational institutions. Examinations are always conducted in the traditional method through physical attendance, paper, and pen. The outbreak of the covid-19 pandemic and a long duration of lockdown is a game-changer towards assessment and educational approaches that differs from traditional face-to-face methods. Therefore, the purpose of this study is to investigate the first online examination experiences and challenges faced by the foundation of science students in the Preparatory Centre for Science and Technology (PPST), Universiti Malaysia Sabah. A presurvey questionnaire was independently developed to study these purposes. A sample of 252 students from intake session 2019/2020 is affected by this COVID-19 pandemic. In addition, the internet connectivity and readiness of the students for their online examinations are the main challenges that are highlighted in this study.

Keywords:

E-Learning, Online Examination, COVID-19, Technology Acceptance, Pandemic 


\section{Introduction}

The recent outbreak of novel coronavirus (COVID-19) which spread rapidly worldwide, caused governments in many countries to take stern action to control the spreading. In the research from Aw et al. (2021), some governments-imposed restriction of movement, quarantine, and even a state lockdown that halted almost all activities. Education sector is one of the worst affected sectors by this pandemic, education institutions are forced to close, academic schedules are delayed, and teaching-learning converted to online platforms. On top of that examinations are also forced to be done online replacing the proven effective traditional physical examination that has been implemented for decades (Sharin, 2021; Al-Kumaim et al., 2021; Kamal et al., 2020; Hillier \& Lyon, 2018)

In Malaysia, the government has imposed three versions of Movement Control Order (MCO) to fight and try to contain the COVID-19 infection rate. Students are required to follow online learning and denied entry to their universities and colleges for safety reasons. The advancement of technology and the internet access in Malaysia for the past years does help to ease the implementation of online education. However, in rural areas of some states the accessibility of internet connection is a great challenge which makes online examinations either difficult or in some cases impossible to access (Abdul Rahim, 2020). In the case of unavailability of internet connection some students stayed temporarily at their relative house, coming to the nearby town or city, or looking for higher ground to get better connection.

Working adults are more exposed and familiar with how online examinations are done, however that is not the case for students, as they need to adapt into this new norm where teaching and learning as well as examinations are held online. COVID-19 stormed the world sometime at the end of Dec 2019 to early Feb 2020 in some countries. These times are crucial for the education sector as many parts of the world have started their teaching-learning season. Thus, it disrupts the teaching-learning session immensely, resulting in conversion of all teaching-learning activities and examinations to online. Education institutions are left without much option other than to cease their activities. It left students with less time for preparation and coping with the new system and examination format that was newly imposed, while many students are already dealing with high anxiety levels adversely affecting their self-efficacy due to the COVID-19 pandemic (Kamaludin et al., 2020).

Online examinations have changed the education landscape in Malaysia and the world. The experience might be great for some students but awful for others. Every student faces different challenges towards the online examination (Karal et al., 2011). Post COVID-19 pandemic might influence educational institutions to improve their online teaching-learning platform and considering the continuity of online examinations as it offers more flexibility and cost efficiency. Having said that, it is advisable for educational institutions to carefully study the effectiveness of online examinations. According to the United Nation's Educational, Scientific and Cultural Organization (UNESCO), over one billion students in 129 countries around the world have their learning progress interrupted by the catastrophic calamity of COVID-19 pandemic (Sundarasen et al., 2020).

Khan et al. (2021) mentioned that online examinations have given lecturers the flexibility of conducting the examination anywhere and anytime required. They would be able to run the examination remotely without being at a specific location, for example at the university. Human error can be lessened through online examinations as answers are computerized and Copyright (C) GLOBAL ACADEMIC EXCELLENCE (M) SDN BHD - All rights reserved 


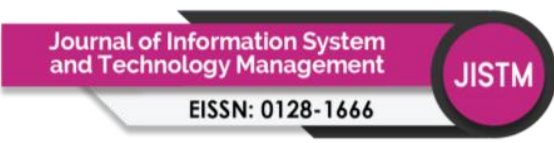

Volume 6 Issue 23 (November 2021) PP. 156-163

DOI: 10.35631/JISTM.623014

Special Issue: Foundation Program Education Post-Covid-19: Issues and Opportunities pre-prepared. Examination results can be produced as soon as the examinations are done. Many researchers agree that some of the biggest challenges of online examination is the technical issue involving internet connection, device compatibility, and digital literacy (Asgari et al., 2021; Peytcheva-Forsyth \& Aleksieva, 2021; Sarrayrih \& Ilyas, 2013; Alruwais, 2018).

Furthermore, it is discovered that online examinations create high anxiety among students and cheating becomes easier because of the limited method monitoring during examinations. Thus, the examination results are improper and cannot represent the student's real performance (Khan et al., 2021). In Malaysia for instance, some rural areas in a few states have limited internet access. LoBue (2020) proposed that by using low bandwidth platforms such as Google Classroom, email, Telegram, WhatsApp \& video conferencing without turning on the live camera would give advantages to students with poor internet connectivity. Therefore, the purpose of this study is to highlight the experiences and challenges towards online examination in Preparatory Centre for Science and Technology (PPST), Universiti Malaysia Sabah.

\section{Methodology}

\section{Research Design \& Sample of Study}

This study describes the first experiences and challenges in conducting online final examinations at the Preparatory Centre for Science and Technology, (PPST) Universiti Malaysia Sabah involving 252 students. The programmes selected were in Semester 2, session 2019/2020. Due to sudden conversion to online instructions, caused by the global COVID-19 pandemic, all foundations of science programmes were compelled to move from face-to-face to totally online during a transition period in March 2020. As a result, urgent development of instructional materials and assessment procedures was required. Lecturers at PPST were instructed to concentrate on learning and using smartv3.ums.edu.my (as well as Zoom video conferencing) to transform their instructions to an online version.

\section{Before Examination}

A pre-survey questionnaire was designed independently to investigate the accessibility of the internet by the students at their home and the readiness for online examination. A zoom session was held to brief the students about the format of online examination and the examination instructions. Format for the examination questions were Multiple Choice Questions (MCQ) and short essays. On top of that, an infographic regarding the format and instruction of examination was provided one week earlier.

Google Form and WhatsApp group was chosen as a platform for these examinations. Students are divided into four WhatsApp groups and led by a lecturer in each group (63 students per group). Google Form quizzes are used as an alternative for the online examination platform of PPST students. Furthermore, this platform requires low bandwidth compared with other platforms, this benefits many students as low bandwidth will cope with low internet connection and less data consumption (LoBue, 2020).

\section{During Examination}

An example of the format and details of the online examination for Chemistry subject as shown in Table 1.3 separate Google Forms were used for each subject and these 3 different links will be released to students by stages. The link to the online examination Google Form is released to students 5 minutes before the examination starts. There is a 10-minute break for the lecturer 
Special Issue: Foundation Program Education Post-Covid-19: Issues and Opportunities to check the attendance and the total number of submitted answers before a new link is released. Reminders regarding the time left for each link were announced in the WhatsApp groups.

Table 1: Format of Online Examination for Chemistry Subject Online Final Examination Chemistry, Semester 2, 2019/2020. Platform: Google Form

\begin{tabular}{|c|c|c|c|}
\hline Details & Time & $\begin{array}{c}\text { Questions } \\
\text { Format }\end{array}$ & Method \\
\hline $\begin{array}{c}1^{\text {st }} \text { link with } \\
\text { password }\end{array}$ & $\begin{array}{c}9.00-9.50 \mathrm{am} \\
(50 \text { minutes })\end{array}$ & $\begin{array}{c}\text { MCQ } \\
\text { (23 questions) }\end{array}$ & \multirow{2}{*}{$\begin{array}{l}\text { Setting for the quizzes: } \\
\text { - } \quad \text { All questions are marked as } \\
\text { required. } \\
\text { - Shuffled order of questions } \\
\text { - Shuffled order of answers } \\
\text { - Only use UMS email for login } \\
\text { - Only } 1 \text { submission of google } \\
\text { - form is allowed } \\
\text { - Using Form Limiter to set the } \\
\text { cut-off time }\end{array}$} \\
\hline $\begin{array}{c}2^{\text {nd }} \text { link with } \\
\text { password }\end{array}$ & $\begin{array}{l}10.00-10.40 \\
\text { am } \\
\text { (40 minutes) }\end{array}$ & $\begin{array}{c}\text { MCQ } \\
\text { (23 questions) }\end{array}$ & \\
\hline $\begin{array}{c}3^{\text {rd }} \text { link with } \\
\text { password }\end{array}$ & $\begin{array}{c}10.50-12.20 \\
\text { am } \\
\text { (1 hour } 30 \text { mins })\end{array}$ & $\begin{array}{l}\text { Short Essay } \\
\text { (9 questions) }\end{array}$ & $\begin{array}{l}\text { Students need to upload their } \\
\text { handwritten answer in the google } \\
\text { form. Only } 1 \text { submission of } \\
\text { google form is allowed. }\end{array}$ \\
\hline
\end{tabular}

\section{After Examination}

Following the assessment, a total of 252 submissions were obtained. The online examination system will be shut down at the end of the specified period for the examination, and no responses will be accepted after that time has passed. Some students sought more time, which was interrupted due to technical difficulties and poor internet connectivity. The MCQ questions were graded automatically, whereas the lecturers marked the short essay manually.

\section{Findings and Discussions}

This study obtained general information about the students in terms of their name, current location during online examination, and lecture groups. We can identify some students from rural locations who have weak internet connections based on the survey questions. Students are encouraged to prepare for their examinations by ensuring that they will be in an area with improved internet access. 
Special Issue: Foundation Program Education Post-Covid-19: Issues and Opportunities

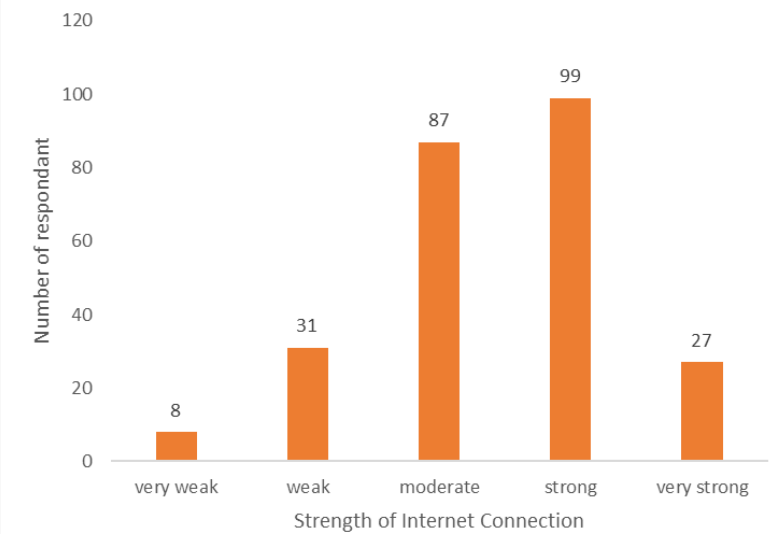

\section{Figure 1: Internet Connectivity Strength Depending on The Student's Examination Location}

Findings as shown in Figure 1 demonstrates the strength of internet connectivity of each student at different locality prior to examination day. A total of 39 students $(15.5 \%)$ declared to have weak to very weak internet access mostly live-in rural areas in Malaysia. On the other hand, $50 \%$ students (126) claimed to have strong to very strong internet access prior to online examination, whereas the remaining 87 students $(34.5 \%)$ reported to have moderate internet strength.

Apart from the students' internet connection, their readiness for the online exam was also a major concern in this research. According to Figure 2, 62\% of the students were not prepared to take an examination via online platform while the remaining $38 \%$ looking forward for the new experience of taking an online exam. Despite the fact that the majority of students stated that they were not prepared to take an online exam, $100 \%$ of students participated and submitted their answers in the online exam.

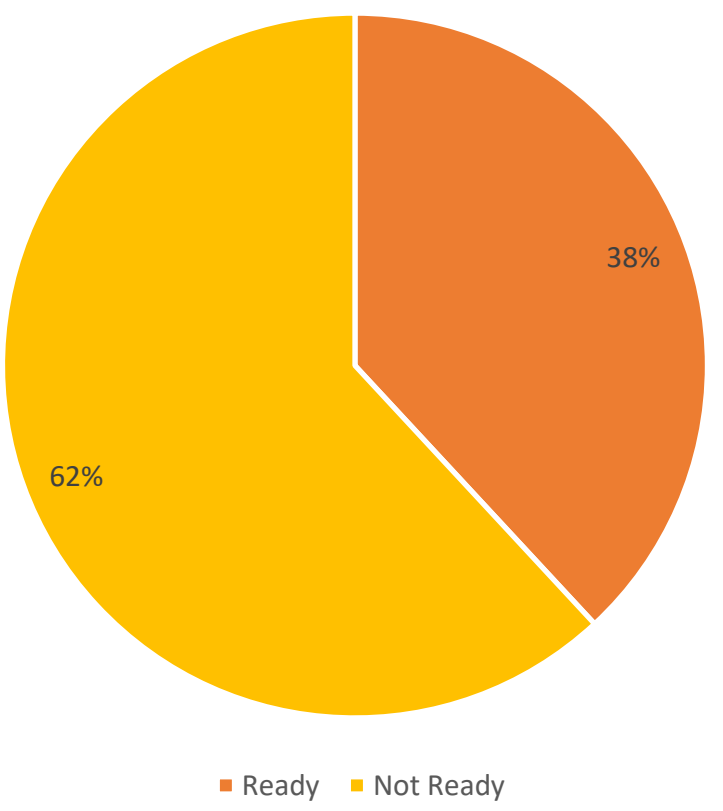

Figure 2: The Student's Readiness towards Online Examination 
Education is one of the most important aspects of human development; it enables individuals improve their economic growth and personalities. Thus, the continuity of education during the COVID-19 pandemic is one of the major concerns for every government to ensure their development plan remain intact. Online teaching-learning and examination brought a new life to education sector, it allows education activities to continue in safe environment. Students and lecturer around the world have been adapting to the online education to ensure the continuity of education, experience and challenge are vary for both student and lecturer (Arora et al., 2020).

\section{Students' Experiences and Challenges}

During the pre-pandemic most of students are not very familiar with online learning and examination. Some students are casually involved in online group discussion or attended short online courses to enhance their general knowledge. However, when the COVID-19 pandemic strikes the world, online education becomes the only source for education. Students across the world is forced to switch to online learning. Adaptation to online assessment at such short notice was a challenge interrogating rigor and standards (Kamaludin et al., 2020; Arora et al., 2020).

Online learning can be very difficult, especially for students that have poor internet access, as it causes issues such as disconnections during online classes, audio disruptions, and time consuming in loading learning materials. The level of focus during studying online compared with physical class is different, student might not be able to give full attention during online classes as they are other factors that could disrupt their focus at home.

Some obstacles and problems encountered by students during online examinations include difficulty logging into UMS email owing to forgotten password, delayed loading of diagrams in questions, and longer time required to upload answer script due to poor internet connectivity. Disruptions in electrical power supply also occur during online examinations; this is a very unpredictable issue that can lead students to disconnect from the exam and have to start over.

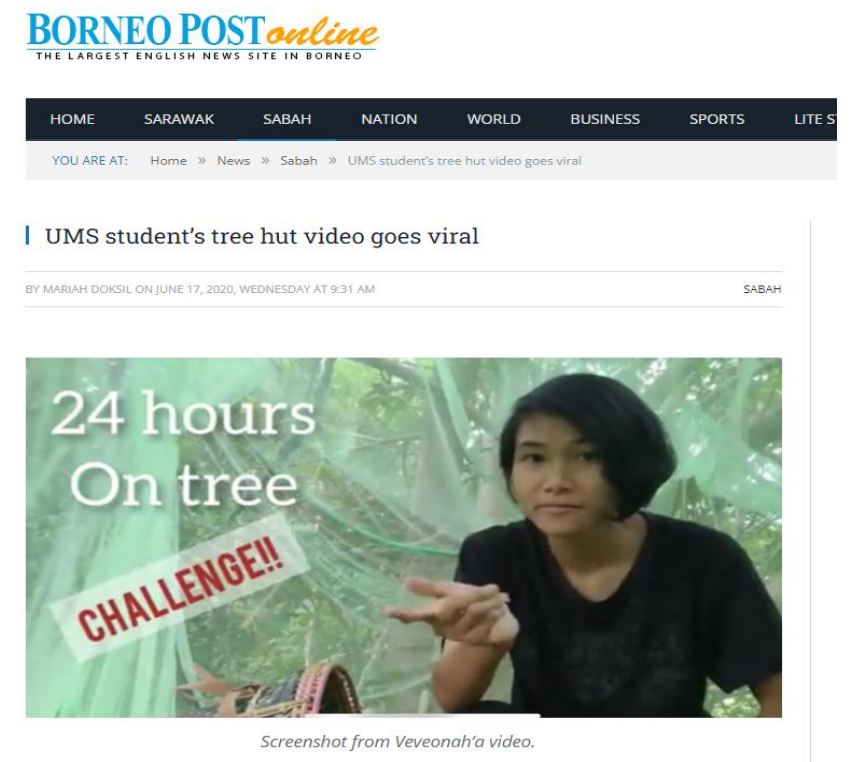

Figure 3: Screenshot from Borneo Post Online (Doksil, 2020) 
A student of Preparatory Centre for Science and Technology University of Malaysia has recently caught the eye of the world because of a video she shared about the challenges she faces during her online examination. Doksil (2020) reported on a UMS student's tree hut video goes viral. Ms Veveonah went viral, and her story was picked up by international news (Lee, 2020). In a video she uploaded, she showed how difficult online learning can be for some students, especially those who reside in rural areas with restricted internet access. Veveonah showed that to take the exam, she must build a temporary tent on higher ground and spend the night there because the tent is distant from her home and the exam begins early in the morning. Apart from the poor internet access, limitation of device might be an issue for family with more than one child that need to attend online learning. Sharing a device to study online can be a hassle and ineffective.

\section{Faculty Experiences and Challenges}

The experience and challenges of online teaching and examination are far more extensive for lecturers. When compared to a physical class, it is more challenging for a lecturer to keep all their students' attention during online sessions. Switching examination into online will cause potential dishonesty and cheating among students. Lecturers will have to deal with student lack of integrity, as certain students may disobey the regulations that have been established. Despite these constraints, online learning and examination reduces human error in question preparation, is less time demanding, and is more environmentally friendly than paper-based learning and examination. Moreover, results of an exam can be produced immediately after the exam due to automatic grading by system especially for multiple choice sections.

\section{Limitation of the Study}

The current study did not assess the effectiveness and long-term viability of the implemented approach. It also did not compare the efficacy of various alternative assessment methods for chemistry online examination. A follow-up study is needed to address this limitation.

\section{Conclusion}

In the light of the findings from the research, the primary problem of these students experienced during online examination was poor internet connectivity. This results in delayed loading of diagrams in questions, and longer time required to upload answer script in the Google Form. Despite the challenges they experience during Movement Control Order (MCO) and majority of students were not ready, all PPST students show excellent dedication and enthusiasm in participating in their first online examination.

\section{References}

Abdul Rahim, A. F. (2020). Guidelines for Online Assessment in Emergency Remote Teaching during the COVID-19 Pandemic. Education in Medicine Journal, 12(2), 59-68.

Al-Kumaim, N. H., Alhazmi, A. K., Mohammed, F., Gazem, N. A., Shabbir, M. S., \& Fazea, Y. (2021). Exploring the Impact of the COVID-19 Pandemic on University Students' Learning Life: An Integrated Conceptual Motivational Model for Sustainable and Healthy Online Learning. Sustainability, 13(5), 2546.

Alruwais, N., Wills, G., \& Wald, M. (2018). Advantages and Challenges of Using eAssessment. International Journal of Information and Education Technology, 8(1), 3437. 


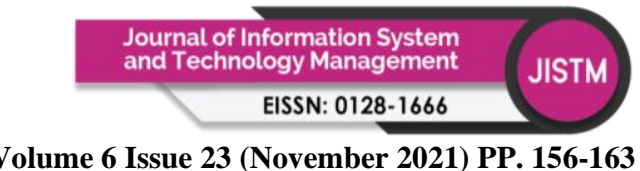

Volume 6 Issue 23 (November 2021) PP. 156-163

DOI: 10.35631/JISTM.623014

Special Issue: Foundation Program Education Post-Covid-19: Issues and Opportunities

Asgari, S., Trajkovic, J., Rahmani, M., Zhang, W., Lo, R. C., \& Sciortino, A. (2021). An observational study of engineering online education during the COVID-19 pandemic. PLOS ONE, 16(4), e0250041.

Aw, S. B., Teh, B. T., Ling, G. H. T., Leng, P. C., Chan, W. H., \& Ahmad, M. H. (2021b). The COVID-19 Pandemic Situation in Malaysia: Lessons Learned from the Perspective of Population Density. International Journal of Environmental Research and Public Health, 18(12), 6566.

Doksil, M. (2020, June 17). UMS student's tree hut video goes viral. Borneo Post Online. https://www.theborneopost.com/2020/06/17/ums-students-tree-hut-video-goes-viral/

Hillier, M. \& Lyon, N. Student experiences with a bring your own laptop e-Exam system in pre-university college. (2018, June). Open Conference on Computers in Education, IFIP TC3. Linz, Austria.

Kamal, A. A., Mohd, N., Truna, L., Sabri, M., \& N., S. (2020). Transitioning to Online Learning during COVID-19 Pandemic: Case Study of a Pre-University Centre in Malaysia. International Journal of Advanced Computer Science and Applications, 11(6).

Kamaludin, K., Chinna, K., Sundarasen, S. D. D., Khoshaim, H. B., Nurunnabi, M., Baloch, G., Sukayt, A. \& Hossain, S. F. A. (2020). Coping with COVID-19 and movement control order (MCO): experiences of university students in Malaysia. Heliyon, 6(11), e05339.

Karal, H., KOKOÇ, M. \& Şılbır, L. (2011). Problems Encountered by Distance Education Students in Online Test Module: A Case Study From the Distance Education Research and Application Center, Karadeniz Technical University, Turkey. US-China Education Review, (6), 768-773.

Khan, M.A., Vivek, V., Khojah, M., Nabi, M.K., Paul, M. \& Minhaj, S.M. (2021). Learners' Perspective towards E-Exams during COVID-19 Outbreak: Evidence from Higher Educational Institutions of India and Saudi Arabia. Int. J. Environ. Res. Public Health, (18), 6534.

Lee, T. Y. (2020, June 18). Malaysian student sits exams in a tree to ensure good wifi. BBC News. https://www.bbc.com/news/blogs-news-from-elsewhere-53079907/

LoBue, A. (2020). Low-Bandwidth Teaching Strategies in Response to the COVID-19 Pandemic. Addressing Technology Access Inequity in Distance Learning and Online Education.

https://edredesign.org/files/edredesign/files/low_bandwidth_teaching_strategies_2.pdf $? \mathrm{~m}=1596823789 /$

Peytcheva-Forsyth, R. \& Aleksieva, L. (2021). Forced introduction of e-assessment during COVID-19 pandemic: How did the students feel about that? (Sofia University case). AIP Conference Proceedings, (2333), 050013-1 - 050013-11.

Sarrayrih, M. A. \& Ilyas, M. (2013). Challenges of Online Exam, Performances and Problems for Online University Exam. International Journal of Computer Science, 10(1), 439443.

Sharin, A. N. (2021). E-learning During Covid-19: A Review of Literature. Jurnal Pengajian Media Malaysia, 23(1), 15-28.

Sundarasen, S. D. D., Chinna, K., Kamaludin, K., Nurunnabi, M., Baloch, G., Khoshaim, H. B., Hossain, S. F. A. \& Sukayt, A. (2020). Psychological Impact of COVID-19 and Lockdown among University Students in Malaysia: Implications and Policy Recommendations. International Journal of Environmental Research and Public Health, (17), 6206.

Copyright $\odot$ GLOBAL ACADEMIC EXCELLENCE (M) SDN BHD - All rights reserved 